\title{
Growth, Flowering Behaviour and Physical Fruit Parameters of Chilli (Capsicum annum L.) Genotypes in Coastal Maharashtra
}

\author{
N. Yatagiri ${ }^{1}$, P.B. Sanap ${ }^{1}$ and R.K. Telugu ${ }^{2 *}$ \\ ${ }^{1}$ Department of Horticulture, Dr. Balasaheb Sawant Konkan Krishi Vidyapeet, \\ Dapoli - 415712 (Maharashtra), India \\ ${ }^{2}$ Department of Vegetable Science, Chaudhary Charan Singh Haryana Agricultural University, \\ Hisar-125004 (Haryana), India \\ *Corresponding author
}

\begin{tabular}{|c|c|}
\hline & A B S T R A C T \\
\hline & A field experiment was conducted at the Central Experiment Station Wakawali during \\
\hline Keywords & $\begin{array}{l}\text { appropriate chilli genotypes under Konkan conditions. The row and plant spacing was } \\
\text { maintained at } 60 \mathrm{~cm} \text { and } 45 \mathrm{~cm} \text { respectively and each plot accommodated } 20 \text { plants. A }\end{array}$ \\
\hline $\begin{array}{l}\text { Chilli, Growth, } \\
\text { Flowering, Fruit } \\
\text { Position, } \\
\text { Genotype. }\end{array}$ & $\begin{array}{l}\text { total of } 19 \text { genotypes of chilli (Capsicum annum } \mathrm{L} \text {.) were evaluated for growth parameters, } \\
\text { flowering behavior and quality parameters which varied significantly. Further plant height } \\
\text { at } 30 \text { DAT (days after transplanting) was observed maximum in genotype } \mathrm{T}_{2} \text { 'LCA-206' } \\
(31.20 \mathrm{~cm}), 60 \text { DAT genotype } \mathrm{T}_{3} \text { 'LCA-334' }(47.40 \mathrm{~cm}), 90 \text { DAT genotype } \mathrm{T}_{18} \text { 'Karvir }\end{array}$ \\
\hline Article Info & Local' $(66.10 \mathrm{~cm})$ and at last harvest stage genotype $\mathrm{T}_{3}$ 'LCA-334' $(70.20 \mathrm{~cm})$ should \\
\hline $\begin{array}{l}\text { Accepted: } \\
\text { 26 June } 2017 \\
\text { Available Online: } \\
10 \text { July } 2017\end{array}$ & $\begin{array}{l}\text { was recorded } \mathrm{T}_{1} \text { (Konkan Kirti) genotype. The maximum average plant spread was } \\
\text { observed in genotype } \mathrm{T}_{19} \text { 'Pachora Local' }(53.85 \mathrm{~cm}) \text {. In case of flowering behavior, } \\
\text { genotypes } \mathrm{T}_{3} \text { (LCA-334) and } \mathrm{T}_{18} \text { (Karvir Local) were found to be early flowering. These } \\
\text { genotvpes were also recorded with desirable values for physical fruit parameters like fruit }\end{array}$ \\
\hline & behavior and fruit positions. \\
\hline
\end{tabular}

\section{Introduction}

Chilli (Capsicum annum L.) is one of the most important commercial crops of India. It belongs to the genus Capsicum under the family Solanaceae. Chilli is an indispensable spice, due to its pungency, taste, appealing colour and flavor.

It is the second largest commodity after black pepper (Piper nigrum L.) in the international spice trade. In India, it is an important ingredient in daily cuisine and is also used in the preparation of pickles, chutneys, sauces etc. The pungency in chilli is due to a crystalline, acrid, volatile alkaloid, capsaicin present in placenta and pericarp of the fruit which has high diverse prophylactic and therapeutic uses in Allopathic and Ayurvedic medicine value.

Despite continuous efforts by the researchers and other stake holders of the crop at various levels, the productivity of the crop has not gained momentum, considering its potential. The low productivity is often attributed to 
many limiting factors such as lack of superior genotypes / improved cultivars for use in breeding programme to develop potential hybrids, severe incidence of insect pests (thrips, mites and borers) and diseases (anthracnose, leaf spots and viral diseases) resulting in tremendous reduction in yield and quality. Further, the high variability present in the crop has so far not been fully exploited in the crop improvement programme.

Studies on chilli genotypes revealed that great variation exists in ability to flowering, fruit set, yield and other qualitative attributes under different agro-climates (Wien et al., 1989; Rani, 1996; Gupta, 2003). There is an ample possibility to increase the productivity by introducing these germplasms. India has large diversity of chilli with different quality factors and other traits. Resistant to biotic and abiotic stress, identification of a variety better suited for a particular region and its improvement is of immediate task to exploit its potential. Therefore, the present study was undertaken to evaluate the growth, flowering behavior and physical fruit parameters in various chilli genotypes in costal Maharashtra.

\section{Materials and Methods}

The experiment was conducted at the Vegetable Improvement scheme, Central Experimental Station, Wakawali, Dr. Balasaheb Sawant Kankan Krishi Vidyapeeth, Dapoli during the Rabi season. The soil of the experimental field is lateritic in nature and sandy loam in texture. It was acidic in reaction having $\mathrm{pH}$ 6.4. The experiment was laid out in Randomized Block Design (RBD) with 19 genotypes (17 genotypes +2 checks) and 2 replications. Nineteen genotypes were collected from vegetable Improvement scheme Central Experimental Station, Wakawali, Dr. Balasaheb Sawant Kankan Krishi Vidyapeeth, Dapoli, Ratnagiri. 19 genotypes (Fig.1) namely $\mathrm{T}_{1}$ - Konkan Kirti, $\mathrm{T}_{2}$ - LCA-206, $\mathrm{T}_{3}$ - LCA-334, $\mathrm{T}_{4}$ - Arka Supriya, $\mathrm{T}_{5}$ - Jayanti, $\mathrm{T}_{6}-$ Pant- $\mathrm{C}_{3}, \mathrm{~T}_{7}-\mathrm{ACSS}-$ 9818, $\mathrm{T}_{8}$ - Phule Sai, $\mathrm{T}_{9}$ - Pusa Jwala, $\mathrm{T}_{10}$ $\mathrm{DPL}_{1}, \mathrm{~T}_{11}-\mathrm{DPL}_{2}, \mathrm{~T}_{12}-\mathrm{DPL}_{4}, \mathrm{~T}_{13}-$ DPL- $\mathrm{C}_{5}, \mathrm{~T}_{14}$ - Pashighat-1, $\mathrm{T}_{15}$ - Pashighat-2, $\mathrm{T}_{16}$ - Pashighat-5, $\mathrm{T}_{17}$ - Pashighat-7, $\mathrm{T}_{18}$ Karvir Local, $\mathrm{T}_{19}$ - Pachora Local-1 of chilli genotypes allocated in plots of $3.6 \times 2.4$ sq. m size. The row and plant spacing was maintained at $60 \mathrm{~cm}$ and $45 \mathrm{~cm}$, respectively. A basal dose of $150 \mathrm{~kg} \mathrm{~N} 80 \mathrm{~kg} \mathrm{P}_{2} \mathrm{O}_{5}$ and $100 \mathrm{~kg} \mathrm{~K}_{2} \mathrm{O} / \mathrm{ha}$ was applied. Half of the nitrogen and full amount of the phosphorus and potash were given as basal dose at the time of transplanting; remaining half quantity of nitrogen was applied in two split doses at 30 days and 60 days after transplanting. The healthy seedlings of uniform growth and healthy were selected for planting. Light irrigation was given before uprooting seedlings from the nursery beds so that minimum damage may occur to the roots of seedling. Appropriate agronomic practices were followed to raise a good crop. Various observations were recorded on growth parameters viz., Plant height $(\mathrm{cm})$ at 30,60 , 90 DAT \& last harvest stage, Mean number of branches per plant at harvesting time, Average Plant spread $(\mathrm{cm})$, Flowering Observations viz., Days to initiation of flowering, Days to $50 \%$ of flowering, Days to initiation of fruit set, Physical parameter of fruit viz., fruiting behavior, Position of fruit. The recorded data was statistically analyzed by ANOVA method given by Panse and Sukhatme (1967).

\section{Results and Discussion}

\section{Growth parameters}

\section{Plant height}

The plant height represents the extension of primary growth and constitutes an important 
component of plant architecture. The data pertaining to mean height of the plant in chilli varieties under study at different growth stages is presented in table 1 . It was evident from the data that plant height differed significantly in chilli varieties at various growth stages. Generally, plant height increased from transplanting $1^{\text {th }}$ month onwards, reaching its maximum height at $4^{\text {th }}$ month and then it declined at the last harvest stage. All the genotypes showed similar trend. By and large, significant variations in the plant height were observed among chilli varieties at all the stages of plant growth. The maximum plant growth period were observed in between 60 days to 90 days after transplanting (DAT).

At 30 DAT the maximum plant height was observed in the $\mathrm{T}_{2}$ 'LCA-206' $(31.20 \mathrm{~cm})$ followed by $\mathrm{T}_{11}$ ' $\mathrm{DPL}-\mathrm{C}_{1}$ ' $(31.10 \mathrm{~cm})$ and minimum was recorded in the $\mathrm{T}_{16}$ 'Pashighat5' $(16.70 \mathrm{~cm})$ followed by $\mathrm{T}_{17}$ 'Pashighat-7' $(18.50 \mathrm{~cm})$. The treatment, $\mathrm{T}_{2}$ 'LCA-206' was significantly superior to all the treatments except $T_{1}$ and $T_{11}$ which were statistically at par. At 60 DAT the maximum plant height was observed in the $\mathrm{T}_{3}$ 'LCA-334' $(47.40 \mathrm{~cm})$ followed by $\mathrm{T}_{18}$ 'Karvir Local' $(47.60 \mathrm{~cm})$ and minimum was recorded in the $\mathrm{T}_{16}$ 'Pashighat-5' $(16.70 \mathrm{~cm})$ followed by $\mathrm{T}_{17}$ 'Pashighat-7' $(21.80 \mathrm{~cm})$. The treatment, $\mathrm{T}_{3}$ 'LCA-334' was significantly superior to all the treatments but was statistically at par with $\mathrm{T}_{12}$ and $\mathrm{T}_{18}$.

At 90 DAT the maximum plant height was observed in $\mathrm{T}_{18}$ 'Karvir Local' $(66.10 \mathrm{~cm})$ followed by $\mathrm{T}_{6}$ 'Pant- $\mathrm{C}_{3}$ ' $(62.00 \mathrm{~cm})$ and minimum in $\mathrm{T}_{16}$ 'Pashighat-5' $(41.00 \mathrm{~cm})$ followed by $\mathrm{T}_{19}$ 'Pachora Local-1' (45.50 $\mathrm{cm})$. The treatment, $\mathrm{T}_{8}$ 'Karvir Local' was significantly superior all the treatments except $\mathrm{T}_{2}, \mathrm{~T}_{3}, \mathrm{~T}_{4}, \mathrm{~T}_{6}, \mathrm{~T}_{7}, \mathrm{~T}_{9}, \mathrm{~T}_{14}$ and $\mathrm{T}_{15}$ which were at par with $\mathrm{T}_{8}$.
At the last harvest stage, the maximum plant height was observed in the $\mathrm{T}_{3}$ 'LCA-334' $(70.20 \mathrm{~cm})$ followed by $\mathrm{T}_{18}$ 'Karvir Local' $(69.50 \mathrm{~cm})$ and minimum was recorded in the $\mathrm{T}_{1}$ 'Konkan Kirti' $(48.90 \mathrm{~cm})$ followed by $\mathrm{T}_{5}$ 'Jayanti' $(53.00 \mathrm{~cm})$. The treatment, $\mathrm{T}_{3}$ 'LCA206' was significantly superior all the treatments except $\mathrm{T}_{2}$ and $\mathrm{T}_{18}$.

The difference observed in the plant height of the different genotypes at different stages of crop growth could be attributed to their genotype characteristics. This may be due to difference in the genotypes genetic makeup, environment and soil of the Konkan region. These results are in accordance with the finding of Smitha and Basavaraja (2006), Phulari (2012) and Tembhurne et al., (2008).

\section{Number of branches per plant}

The data recorded on number of branches produced per plant at last harvest in all the varieties are presented in table 1. From the data it was observed that the number of branches produced per plant varied significantly in chilli genotypes during last harvest of growth.

The genotypes at last harvest stage produced maximum branches in $\mathrm{T}_{1}$ 'Konkan kirti' (9.55) followed by $\mathrm{T}_{9}$ 'Pusa Jwala' (8.59) and minimum number of branches per plant were produced in $\mathrm{T}_{8}$ 'Phule Sai' (3.25) followed by $\mathrm{T}_{16}$ 'Pashighat-5' (4.25). The treatment, $\mathrm{T}_{1}$ 'Konkan kirti' was significantly superior to all the treatments but was statistically at par with $\mathrm{T}_{3}, \mathrm{~T}_{6}, \mathrm{~T}_{9}$ and $\mathrm{T}_{12}$.

Such variation in the number of branches per plant may be due to genotypes characteristic of genotypes, interaction with environment and soil factors. These results are conformity with the findings of Amith et al., (2014), Ukkud et al., (2007) and Vijaya et al., (2014). 


\section{Plant spread (cm)}

Plant spread is the results of process of differentiation occurring in plant. It was observed that the maximum plant spreads was recorded at last harvest in all the genotypes (Table 1).

It was observed from the data that the plant spread differed significantly in chilli genotypes during last harvest stage.

The maximum plant spread was observed in genotype $\mathrm{T}_{19}$ 'Pachora Local' $(53.85 \mathrm{~cm})$ followed by $\mathrm{T}_{12}$ 'DPL-C 4 ' $(52.10 \mathrm{~cm})$ which was significantly superior to all the varieties at last harvest days stage.

The minimum plant spread was observed in the genotype $\mathrm{T}_{17}$ 'Pshighat-7' $(40.50 \mathrm{~cm})$ followed by $\mathrm{T}_{8}$ 'Phule Sai' $(41.55 \mathrm{~cm})$. The treatment, $\mathrm{T}_{19}$ 'Pachora Local' was significantly superior to all the treatments.

The wide range of variation in the plant spread observed may be due to direct effect of soil and agro-climatic condition of the Konkan region and indirect effect of number of branches per plant.

Significant variations in plant spread were reported by Nehru et al., (2003), Smitha and Basavaraja (2006).

\section{Flowering characteristics}

\section{Days to initiation of flowering}

The data pertaining to the number of days to initiation of flowering is presented in table 1 . The minimum number of days to initiation of flowering was observed in the genotypes $\mathrm{T}_{3}$ 'LCA-206' and $\mathrm{T}_{18}$ 'Karvir Local' genotypes of chilli (41.50) and maximum days in the genotype $\mathrm{T}_{17}$ 'Pashighat-7' (80.50) followed by $\mathrm{T}_{19}$ 'Pachora Local' (74.50).
The treatment $\mathrm{T}_{3}$, 'LCA-206' and $\mathrm{T}_{18}$ 'Karvir Local' were significantly superior to all the treatments except $\mathrm{T}_{5}$ and $\mathrm{T}_{16}$.

The variation in days to initiation of flowering might be due to moderately genetic factors of varieties, less influence by hormonal factors and environmental factors.

The results are in conformity with the findings of Manju and Sreelathakumary (2002) and Amit et al., (2014).

\section{Days to $50 \%$ of Flowering}

The data pertaining to the number of days to $50 \%$ of flowering are presented in table 1 . It was noticed that the genotype $\mathrm{T}_{18}$ 'Karvir Local' required minimum days (45.50) followed by $\mathrm{T}_{3}(46.00)$ and maximum days in the $\mathrm{T}_{17}$ 'Pashighat-7' (84.50), followed by $\mathrm{T}_{19}$ 'Pachora Local' (78.50) days. The treatment, $\mathrm{T}_{18}$ 'Karvir Local' was significantly superior to all the treatments except $\mathrm{T}_{5}$ and $\mathrm{T}_{16}$.

The variation of the days to $50 \%$ flowering may be due to highly genetic makeup of genotypes, less environmental, and vigor growth of crop (Chaitali, 2014) Similar results were also observed by Shiva et al., (2013), Chattopadhyay (2011), Pulari (2013), Vijaya et al.,(2014).

\section{Days to initiation of fruit set}

The data pertaining to the number of days to initiation of fruiting are presented in table 1. It was noticed that the genotype $\mathrm{T}_{18}$ 'Karvi Local' required minimum (48.50) number of days followed by $\mathrm{T}_{3}$ 'LCA-206' (49.50) days and in the genotype $\mathrm{T}_{17}$ 'Pashighat-7' required maximum number of days (88.54) followed by $\mathrm{T}_{19}$ 'Pachora Local' (82.50) days. The treatment, $\mathrm{T}_{18}$ Karvi Local' was significantly superior to all the treatments except $\mathrm{T}_{3}$ and $\mathrm{T}_{16}$. 
Table.1 Mean plant height (cm) at 30, 60, 90 DAT and Last harvest stage, Number of branches/plant, average plant spread (cm), Days to initiation of flowering, Days to $50 \%$ of flowering, Days to initiation of fruit set of various chilli genotypes tested at Konkan agro climatic condition

\begin{tabular}{|c|c|c|c|c|c|c|c|c|c|}
\hline \multirow[b]{2}{*}{ Treatments } & \multicolumn{4}{|c|}{ Plant height $(\mathrm{cm})$} & \multirow[b]{2}{*}{$\begin{array}{c}\text { Number of } \\
\text { branches/plan } \\
t\end{array}$} & \multirow[b]{2}{*}{$\begin{array}{c}\text { plant } \\
\text { spread } \\
(\mathbf{c m})\end{array}$} & \multirow{2}{*}{$\begin{array}{c}\text { Days to } \\
\text { initiation } \\
\text { of } \\
\text { flowering }\end{array}$} & \multirow{2}{*}{$\begin{array}{l}\text { Days to } \\
50 \% \text { of } \\
\text { flowering }\end{array}$} & \multirow{2}{*}{$\begin{array}{c}\text { Days to } \\
\text { initiation } \\
\text { of fruit } \\
\text { set }\end{array}$} \\
\hline & $\begin{array}{c}30 \\
\text { DAT }\end{array}$ & $\begin{array}{c}60 \\
\text { DAT }\end{array}$ & $\begin{array}{c}\text { 90DA } \\
\mathrm{T}\end{array}$ & $\begin{array}{c}\text { Last } \\
\text { harvest }\end{array}$ & & & & & \\
\hline $\mathrm{T}_{1}-$ Konkan Kirti & 30.00 & 38.10 & 46.00 & 48.90 & 9.55 & 46.50 & 49.50 & 54.50 & 58.50 \\
\hline $\mathrm{T}_{2}-\mathrm{LCA}-206$ & 31.20 & 37.10 & 59.20 & 66.90 & 7.80 & 49.05 & 47.50 & 53.50 & 56.50 \\
\hline $\mathrm{T}_{3}-\mathrm{LCA}-334$ & 30.90 & 47.40 & 61.90 & 70.20 & 8.40 & 50.10 & 41.50 & 46.50 & 49.50 \\
\hline $\mathrm{T}_{4}-$ Arka Supriya & 23.30 & 33.40 & 57.10 & 63.50 & 7.30 & 51.65 & 47.50 & 51.50 & 54.50 \\
\hline $\mathrm{T}_{5^{-}}$Jayanti & 23.70 & 37.60 & 47.80 & 53.00 & 7.70 & 46.75 & 42.50 & 46.50 & 50.50 \\
\hline $\mathrm{T}_{6}-$ Pant- $\mathrm{C}_{3}$ & 18.90 & 34.70 & 62.00 & 64.70 & 8.50 & 51.05 & 55.50 & 60.50 & 63.50 \\
\hline $\mathrm{T}_{7}-\mathrm{ACSS}-9818$ & 23.60 & 33.80 & 59.40 & 62.00 & 8.10 & 47.02 & 51.50 & 54.50 & 57.50 \\
\hline $\mathrm{T}_{8}-$ Phule Sai & 18.70 & 24.80 & 41.70 & 54.20 & 3.25 & 41.55 & 53.50 & 57.50 & 61.50 \\
\hline $\mathrm{T}_{9}$ - Pusa Jwala & 23.62 & 34.30 & 54.65 & 60.85 & 8.59 & 51.60 & 53.50 & 58.50 & 63.50 \\
\hline $\mathrm{T}_{10}-\mathrm{DPL}-\mathrm{C}_{1}$ & 23.63 & 38.40 & 50.85 & 58.70 & 6.50 & 47.00 & 45.50 & 50.50 & 53.50 \\
\hline $\mathrm{T}_{11}-\mathrm{DPL}-\mathrm{C}_{2}$ & 31.10 & 38.80 & 52.10 & 59.00 & 7.90 & 42.95 & 45.50 & 51.50 & 53.50 \\
\hline $\mathrm{T}_{12}-\mathrm{DPL} \mathrm{C}_{4}$ & 23.87 & 40.40 & 50.80 & 54.20 & 8.45 & 52.10 & 45.50 & 50.50 & 54.00 \\
\hline $\mathrm{T}_{13}-\mathrm{DPL} \mathrm{C}_{5}$ & 23.60 & 38.00 & 50.50 & 55.80 & 7.55 & 47.80 & 47.50 & 51.50 & 54.50 \\
\hline $\mathrm{T}_{14}$ - Pashighat-1 & 23.87 & 26.35 & 54.30 & 58.15 & 7.35 & 42.80 & 47.50 & 51.50 & 55.50 \\
\hline $\mathrm{T}_{15}$ - Pashighat-2 & 19.20 & 23.60 & 58.00 & 63.50 & 6.90 & 47.75 & 46.50 & 50.50 & 54.50 \\
\hline $\mathrm{T}_{16}$ - Pashighat-5 & 16.70 & 19.80 & 41.00 & 53.60 & 6.10 & 42.40 & 42.50 & 47.00 & 50.00 \\
\hline $\mathrm{T}_{17}$ - Pashighat-7 & 18.50 & 21.80 & 48.40 & 57.80 & 8.25 & 40.50 & 80.50 & 84.50 & 88.54 \\
\hline $\mathrm{T}_{18}-$ Karvir Local & 27.50 & 46.50 & 66.10 & 69.50 & 7.10 & 50.60 & 41.50 & 45.50 & 48.50 \\
\hline $\mathrm{T}_{19}$ - Pachora Local-1 & 26.00 & 26.20 & 45.50 & 55.20 & 6.95 & 53.85 & 74.50 & 78.50 & 82.50 \\
\hline S.E \pm & 2.31 & 2.84 & 4.64 & 1.24 & 0.40 & 0.46 & 0.50 & 0.54 & 0.61 \\
\hline $\mathrm{CD}$ at $(5 \%)$ & 6.87 & 8.45 & 13.78 & 3.67 & 1.20 & 1.34 & 1.49 & 1.61 & 1.81 \\
\hline
\end{tabular}


Table.2 Physical fruit parameters of various chilli genotypes

\begin{tabular}{|c|c|c|c|c|}
\hline Genotypes & Fruiting behavior & Fruit position & Fruit Shape & Fruit colour \\
\hline Konkan Kirti & Solitary & Pendent & Long & Dark green \\
\hline LCA-206 & Solitary & Pendent & Very Long & Green \\
\hline LCA-334 & Solitary & Pendent & Long & Green \\
\hline Arka Supriya & Solitary & Pendent & Long & Dark green \\
\hline Jayanti & Solitary & Pendent & Very Long & Green \\
\hline Pant- $\mathrm{C}_{3}$ & Solitary & Pendent & Long & Green \\
\hline ACSS-9818 & Solitary & Pendent & Very long & Green \\
\hline Phule Sai & Solitary & Pendent & Long & Green \\
\hline Pusa Jwala & Solitary & Pendent & Long & Light green \\
\hline $\mathrm{DPL}_{-} \mathrm{C}_{1}$ & Solitary & Pendent & shoot & Green \\
\hline $\mathrm{DPL}_{-} \mathrm{C}_{2}$ & Solitary & Pendent & Long & Light green \\
\hline $\mathrm{DPL}_{-} \mathrm{C}_{4}$ & Solitary & Erect & shoot & Green \\
\hline $\mathrm{DPL}_{-C_{5}}$ & Solitary & Pendent & Long & Green \\
\hline Pashighat-1 & Solitary & Erect & shoot & Green \\
\hline Pashighat-2 & Solitary & Pendent & Long & Green \\
\hline Pashighat-5 & Solitary & Pendent & Long & Green \\
\hline Pashighat-7 & Solitary & Pendent & shoot & Green \\
\hline Karvir Local & Solitary & Pendent & Very Long & Green \\
\hline Pachora Local-1 & Solitary & Pendent & Long & Green \\
\hline
\end{tabular}

Fig.1 Various chilli genotypes of fruit shape and fruit colour

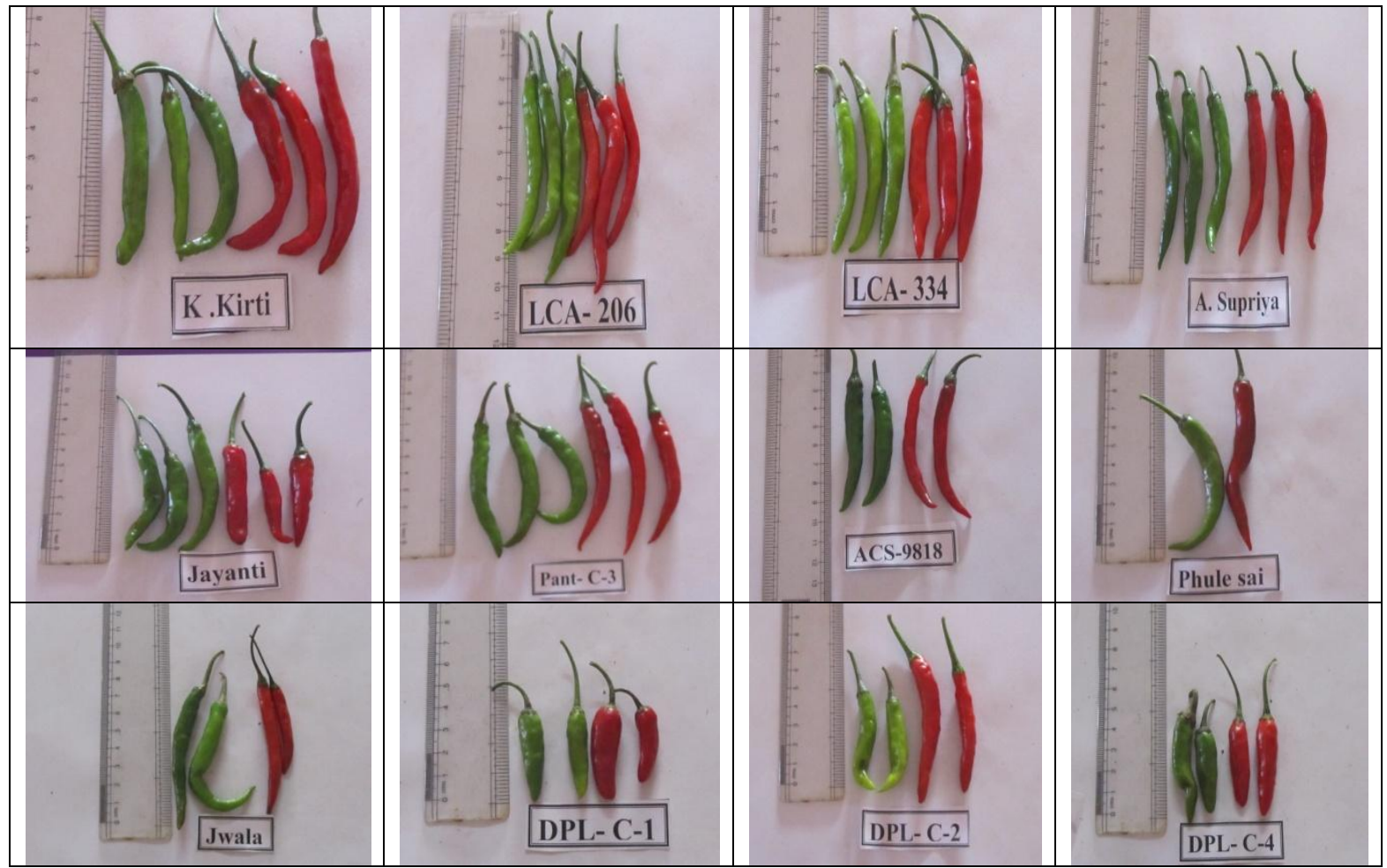




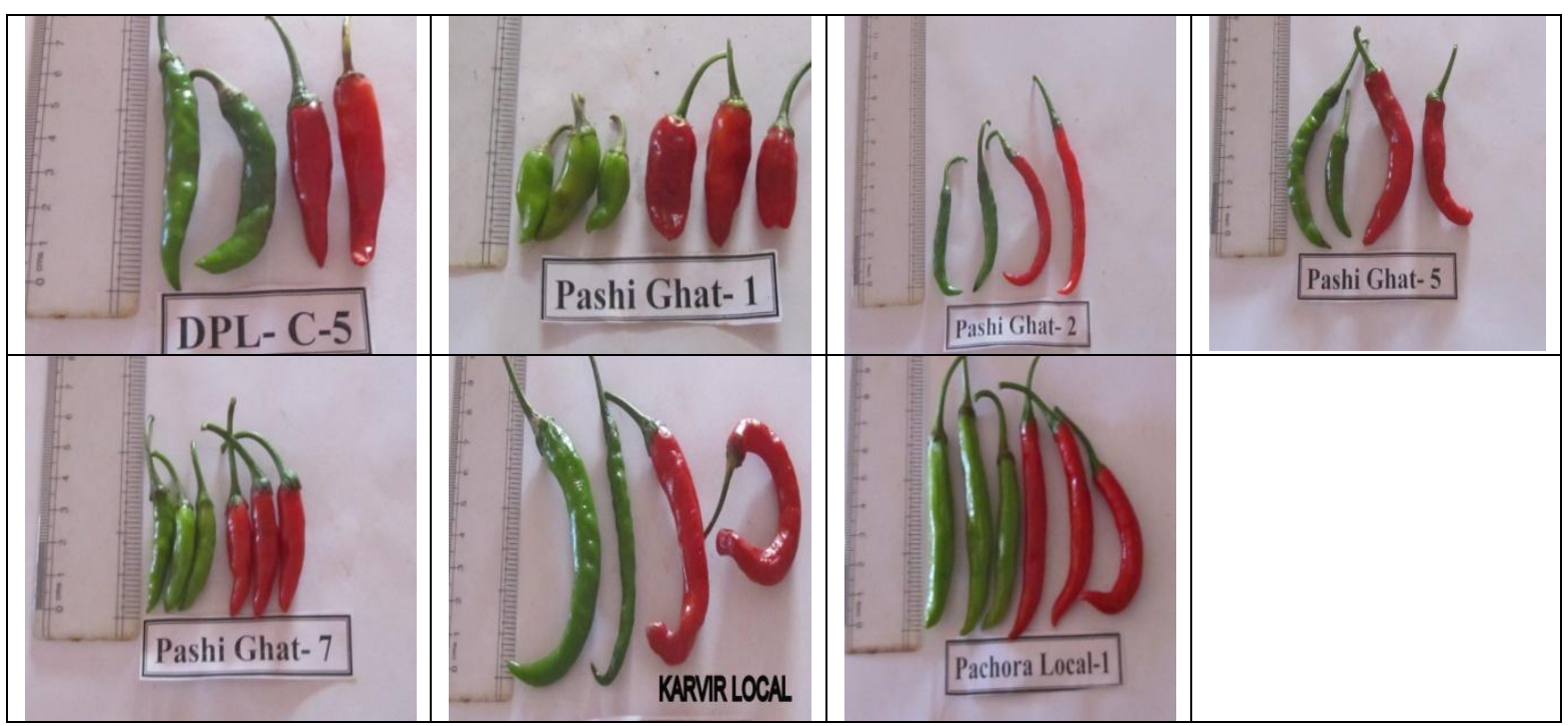

Such variations of treatments were due to genetic influence of genotypes and environmental conditions. Vijaya et al., (2014), Phulari (2012) and Amit et al., (2014) reported similar results on chilli genotypes.

\section{Physical Fruit parameters}

\section{Fruiting behavior}

From table 2 it is revealed that the all genotypes showed similar character of fruiting behavior 'Solitary'. This might be due to highly effect of genetic behavior of genotypes, less influence weather condition of Konkan region. These results are in recored with those of concord Mahmood et al., (2002), Dhamayanthi and Reddy (2003).

\section{Position of fruit}

It is observed from the table 2 that all the genotypes showed in 'Pendent' position habit except genotypes in $\mathrm{T}_{12}$ 'DPL- $\mathrm{C}_{4}$ ' and $\mathrm{T}_{14}$ ' 'Pashighat-1' 'Erect' position.

Variation of the fruit position in different genotypes could be due to variation genotypes characters owing to genetics make up and less effect of environmental factors. Bylla Prasad et al., (2013), Dhamayanthi and Reddy (2003) also found similar results in chilli genotypes.

\section{Fruit shape}

It is revealed that from the table 2 and figure 1 conical shape fruits were observed in genotypes $\mathrm{T}_{12} \quad$ 'DPL-C ${ }_{4}$ ', $\quad \mathrm{T}_{14}$ 'Pashighat-1'and $\quad \mathrm{T}_{17}$ 'Pashighat-7' where as long shape fruits were observed in the genotypes $\mathrm{T}_{10}$ 'DPL- $\mathrm{C}_{1}$ ', $\mathrm{T}_{11}$ 'DPL-C 2 ', $\mathrm{T}_{13}$ 'DPL-C ${ }_{5}$ ', $\mathrm{T}_{15}$ 'Pashighat-2', $\mathrm{T}_{16}$ 'Pashighat-5' and $\mathrm{T}_{17}$ 'Pashighat-7' and very long fruits observed in the genotypes $T_{1}$ 'Konkan kirti', T $T_{2}$ 'LCA-206', T $T_{3}$ 'LCA-334', $\mathrm{T}_{4}$ 'Arka Supriya', $\mathrm{T}_{5}$ 'Jayanti', $\mathrm{T}_{6}$ 'Pant- $\mathrm{C}_{3}$ ', $\mathrm{T}_{7}$ 'ACSS-9818', $\mathrm{T}_{8}$ 'Phule Sai', $\mathrm{T}_{9}$ 'Pusa Jwala', $\mathrm{T}_{18}$ 'Karvir Local' and $\mathrm{T}_{19}$ 'Pachora Local-1'.

The variation may be due to moderately environmental factors and highly genetics factors of genotypes. Similar findings have also been reported by Nkansah et al., (2011), Dhamayanthi and Reddy (2003).

\section{Fruit colour}

From the table 2 and figure 1 it was found that the genotypes $\mathrm{T}_{9}$ 'Pusa Jwala', $\mathrm{T}_{11}$ 'DPL-C ${ }_{2}$ ', were light green in colour whereas genotypes $\mathrm{T}_{2}$ 'LCA-206', $\mathrm{T}_{3}$ 'LCA-334', $\mathrm{T}_{5}$ 'Jayanti', $\mathrm{T}_{6}$ 'Pant-C ${ }_{3}$ ', $\mathrm{T}_{7}$ 'ACSS-9818', $\mathrm{T}_{8}$ 'Phule Sai', $\mathrm{T}_{10}$ 'DPL-C 1 ', $\mathrm{T}_{12}$ 'DPL-C $4, \mathrm{~T}_{13}$ 'DPL-C $_{5}$ ', $\mathrm{T}_{14}$ 'Pashighat-1', $\mathrm{T}_{15}$ 'Pashighat-2', $\mathrm{T}_{16}$ 'Pashighat5', $\left(\mathrm{T}_{17}\right)$ 'Pashighat -7', $\mathrm{T}_{18}$ 'Karvir Local', $\mathrm{T}_{19}$ 'Pachora Local-1' were green in colour and $\mathrm{T}_{1}$ 
'Konkan Kirti', T 4 'Arka Supriya' were dark green colour.

The variation may be ascribed to moderately environmental factors and highly genetics factors. Colour variation was also observed by Chattopadhyay (2011), Sharma et al., (2010) and Nkansah et al., (2011).

Thus, while evaluating the nine teen genotypes of chilli, it can be concluded that on the basis of growth observations, flowering behavior the genotypes LCA-334, Konkan kirti, Karvir Local and Pant- $\mathrm{C}_{3}$ suitable for Konkan region. Also, fruit shape and fruit colour among other traits seems the best genetic marker in chilli identification.

The variation due to may be moderately environmental factors and highly genetic factors of genotypes.

\section{References}

Amit, K., Ahad,I. and Kumar,V. 2014. Genetic variability and correlation studies for

Rani, P.U. 1996. Evaluation of chilli (Capsicum annuum L.) germplasm and its utility in breeding for higher yield and better quality. Maysore J. Agric. Sci., 30: 343348.

Smitha, R.P. and Basavaraja, N. 2006. Variability and Correlation Studies in Chilli (Capsicum annum L.). Karnataka J. Agri Sci., 19 (4): 888-891.

SreelathaKumary, I. and Rajamony, L. 2004. Variabity heritability and genetic advance in Chilli (Capsicum annum. L). $J$. Tropical Agri., 42 (1-2): 35-37.

Tembhurne, B.V., Revenappa and Kuchanur, P.H. 2008. Varietal performance genetic variability and correlation studies in chilli (Capsicum annum L.). Karnataka J. Agri.

\section{How to cite this article:}

Yatagiri, N., P.B. Sanap and Telugu, R.K. 2017. Growth, Flowering Behaviour and Physical Fruit Parameters of Chilli (Capsicum Annum L.) Genotypes in Coastal Maharashtra. Int.J.Curr.Microbiol.App.Sci. 6(7): 2230-2237. doi: https://doi.org/10.20546/ijcmas.2017.607.323 growth and yield characters in chilli (Capsicum annum L.) J. Spices and Aromatic Crops., 23 (2): 170-177.

Dhamanthi, K.P.M. and reddy, V.R.K. 2003. Breeding derivatives with desirable traits using chilli (capsicum annum.L) stocks and popular varieties J. Spices and Aromatic Crops., 12 (2):107-112.

Gupta, M.K. 2003. Performance of chilli (Capsicum annuum L.) genotypes under tarai condition of uttranchal. Thesis, M. Sc. Ag., G. B. Pant University of Agriculture and Technology, Pantnagar, India 123 p.

Mahamood, T., Hussain, S.I., Khokhar, K.M. and Bhatti, H. 2002. Comparative performance of local and exotics chilli cultivars. Asian J. of Plant Sci., 1 (2): 162-163.

Nehru, S.D., Manjunath, A. and Rangaiah, S. 2003. Genetic Variability and Stability for Fruit yield and other Metrical Characters in Chilli (Capsicum annum.L). Karnataka J. Agri. Sci., 16 (1): 44-47.

Panse, V.G. and Sukhatme, P.V. 1989. Statistical methods for agricultural workers. Indian Council of Agrcultural Research, New Delhi. 145-150.

Sci., 21 (4): 541-543.

Ukkund, K.M., Madalageri, M.B., Patil, M.P., Mulage, R. and Kotikal, Y.K. 2007. Variability studies in green Chilli (Capsicum annum L.). Karnataka J. Agri. Sci., 20 (1): 102-104.

Wien, H.C., Tripp, K.E., Hernandez-Armetana, R. and Turner, A. D. 1989. Abscission of reproductive structures in pepper: causes, mechanisms and control. In: Tomato and Pepper Production in the Tropics. Proceedings of the International Symposium on Integrated Management Practices. Asian Vegetable Research and Development Centre, Shanhua, Taiwan 150-165 pp. 